\title{
EPHEMERAL ARCHITECTURE - A PROPOSAL FOR INTERVENTIONS IN PUBLIC SPACE
}

\author{
UDC 711.1/.4
}

\author{
Sanja Janković, Danica Stanković \\ University of Niš, Faculty of Civil Engineering and Architecture, Republic of Serbia
}

\begin{abstract}
Most certainly, architectural objectives are the basis of the physical structure of a city, yet they are distinct morphological and typological units, they are free spaces with exceptional values and characteristics. Buildings that form the spaces of cities often change, build and disintegrate, but the permanent motive of the city space remains - an empty, unfinished part, as a constant sign of history. On the hierarchical scale of the urban environment, important elements are ephemeral structures, permanent or temporary. A possibility for empty space to be revived is the installation of artistic or ephemeral utilitarian structures. This paper presents the role of such micro-urban interventions that enrich the public space and contribute to its revitalization. Ephemeral architecture is especially suitable as a space for the presentation of artistic ideas and for incorporating new technological contents. The aim of the paper is to highlight a view about the importance of ephemeral structures by analyzing and studying the case studies. Special emphasis is placed on examples of completed projects of the pavilions of unique forms and the use of ship containers as a space for introducing artistic ideas. The main contribution of this paper should be a proposal of using ephemeral structures in urban space revival by promoting art and establishing a social contact.
\end{abstract}

Key words: Ephemeral architecture, Micro-urban intervention, Installations, Pavilions, Art.

\section{INTRODUCTION}

"The city must be such that people who live in it are not only safe but also happy." (Uzunović, 2009, cited Aristotle).

Aristotle's statement could still be used as a model for the reorganization of public urban spaces, whether it is about the design of these spaces or their reanimation using ephemeral structures. Observing the city as the creation of a man formed as a product of

Received May 2019 / Accepted September 2019

Corresponding author: Sanja Janković

University of Niš, Faculty of Civil Engineering and Architecture

E-mail: sanja.jankovic@ outlook.com 
social, historical, economic and natural influences, we can speak about the greatest urban phenomenon ever created (Uzunović, 2009). By constructing such a unit from which our consideration starts, we reach a structure composed of subcategories, parts, areas.

The built and free spaces for the city are as relevant as the molecules and the intermolecular space for the tissue (Zeković, 2015). All those who professionally deal with space planning should think about this problem. One aspect of this problem relates to ephemeral structures in the urban area.

The subject of this research work is about ephemeral architecture and ephemeral structures in the urban area. In the first part of the paper, the features and the role of the ephemeral architecture will be exposed together with the significance of such structures within the city space. The subject of the paper is the role of micro-urban interventions that enrich the public space and contribute to its revitalization. Likewise, the importance of ephemeral installations as interventions will be presented.

In the second part of the paper, emphasis is placed on examples of completed projects of the pavilions of unique forms and the use of ship containers as the space for the presentation of artistic ideas.

The aim of the paper is to highlight our view about the importance of ephemeral structures by analyzing and studying the case studies and proposing solutions for their wider application in regulating public space.

\section{DEFINITION OF `EPHEMERAL ARCHITECTURE` AND ASPECTS OF ITS INCIDENCE}

'Ephemeral architecture` is architecture that is neither permanent nor is immutable. It tries to regroup architectural objects, based on their actual relationship with time. Ephemeral architecture is a class of architectural objects designed so that they are characterized by transience and their physical disappearance from the site (Zite, 2004).

Ephemeral objects and structures were built with the idea to last for a certain period of time until they fulfill their function - their goal. To be more precise, they last until the needs of the programs that they encompass do not overgrow themselves and do not begin to demand new spatial responses.

Aspects of the incidence of ephemeral portable structures are of great importance function, typology, form, relationship with technology and relationship with the users. Hence, it can be concluded that compared to permanent architectural structures, those who are ephemeral satisfy some of the functions that the previous ones do not satisfy various reasons (Radović, 2003). Due to the possibility of reuse and relying on noninvasive construction methods, ephemeral structures have a low environmental impact and are suitable for quick installation at other locations.

Typologies that are subject to this kind of design are private and public buildings, starting with concert halls, schools, banks, swimming pools, skating rinks, to pavilions and art installations.

The exceptional practice of portable architecture is based on the principles of design efficiency, ease and flexibility, and is especially suitable for incorporating new technological achievements. For new residents of the developed world - urban nomads, portable architecture is the right solution for establishing a mobile home (Gidion, 2002). An important aspect of the phenomenon of ephemeral architecture is the temporal durability of the consequences of the appearance of such a structure, even when its temporality removes evidence of its physical existence. Measuring its quality or its value 
is also a subjective feeling of accomplishing its mission. The subjective feeling about the success of ephemeral architecture on which its duration in memory is dependent and which gives it legitimacy - is the feedback of the user of the given space, or more specifically - the fulfillment of the needs and expectations of the people for whom the objects are designed (Chappel, 2006).

\section{THE Role of EPHEMERAL ARCHITECTURE IN THE PROCESS OF SETTING UP BORDER SPACES IN ARTS}

According to the roles that ephemeral architecture accomplishes in the process of forming boundary spaces in art, it can be stated that it meets:

- Demarking function;

- Morphological function;

- Ambient function;

- Performative function;

- Scene function;

- Technical-technological function.

Ephemeral architecture was built with the intention of receiving some form of artistic activity. However, under the auspices of its utilitarianism, this architecture must fulfill the function of clearly marking the boundary between two forms of real physical reality - the reality of an event that occurs within the space and reality of everyday life that remains outside of it (Kronenburg, 1998).

A demarcation function is defined as a result of a utilitarian function, which changes the idea of functionality as a requirement that fills the architecture. Architecture fulfills its demarcation function through the establishment of a clear, tangible physical boundary, in defining concrete physical integrity.

The morphological function ephemeral architecture fills through a configuration issue, in terms of creating a central space of events (often a binary space).

The ephemeral architecture fills ambient function through the questions about the quality of the environment that it forms, or, in other words, the issues of liberation and the possibility of forming narratives through itself.

The role of space as a subject / actor in the event, or more precisely the role of space as the protagonist of events is essential for the realization of the spectacle and ensuring the development of the necessary reception by observers. This role is realized through the performative function of ephemeral architecture, which, by changing the role from the static framework to the event, becomes a dynamic and active support.

The scene function of the ephemeral architecture considered in this context relates to the questions of scene staging and stage design as a complete, complex, comprehensive concept.

The technical-technological function is usually considered through the issues of harmonization and technology adoption (Pantović, Parežanin, Kavran, 2013).

\section{MiCRO-URbAN INTERVENTIONS IN RENOVATION OF URBAN SPACES}

In the category of micro-urban interventions we can classify all creative, innovative, cheap, random or intentional, ephemeral interventions in the urban area, which can be physical objects or processes, and which can involve a greater or lesser number of people 
organized in formal or informal, self-initiative groups (Mellado, 2012). In this sense, micro-urban interventions include:

- cultural events, exhibitions and festivals - music, film, art, etc.;

- ephemeral installations - artistic or utilitarian;

- ephemeral architectural objects;

- skating parks and other sports facilities;

- drawing graphite as a way of young people expressing themselves, and in this way mainly send certain messages to society, express their political and other attitudes, etc.;

- informal daily gatherings; any kind of people staying in a certain space contributes to the revival of this space and can be taken as the basic prerequisite for revitalization (Walker, 2004).

Based on this division, a more general division of micro-urban interventions into objects (physical, tangible) and processes (activities) can be made. The paper focuses on physical micro-urban interventions, i.e. installations, pavilions and container spaces observed at the level of the ephemeral art installation (Coar, 2011).

\subsection{Useful spatial installations - proposal of interventions in the public space}

Installations are listed as one form of micro-urban intervention, which in general can be classified into artistic and utilitarian. Without deeper involvement in their classification, useful spatial installations can be defined as structures that, in addition to their function, have visual, ambient values, enrich public space, and serve as spatial landmarks and places of assembly and socialization. The influence of spatial installations on the revival of the public space is illustrated by the example of the Origami forum and The bench $1000 \mathrm{~cm}$, whose authors are ModelArt Studio from Novi Sad (members: Dejan Mitov, Jelena Čobanović, Krsto Radovanović and Maja Nogavica). It is about experimental spatial installations / urban 'furniture`, which were created within the scope of the research on the influence of spatial installations on the public space and its revival (source: www.gradjanske.org/wp.../059-Otvoreno-o-javnim-prostorima.pdf, accessed: 12.03.2018.)
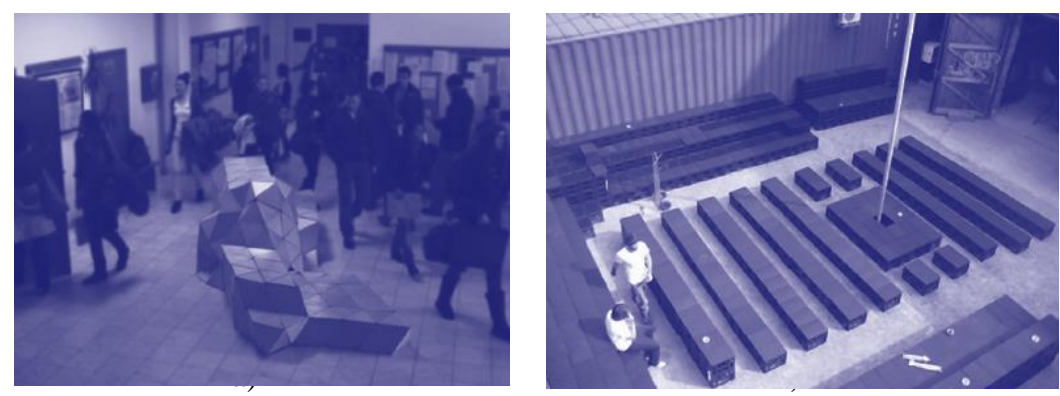

Fig. 1 (a) Origami Forum, (b) Origami Forum changed structure (source: www.gradjanske. org/wp.../059-Otvoreno-o-javnim-prostorima.pdf, accessed: 12.03.2018.)

Origami Forum is a project that was created in 2011 in cooperation with the Faculty of Technical Sciences. It is a structure made of wood-like origami (Figure 1-a), a japanese paper bending skill. By multiplying the triangular plywood element, it is made a 
grid that is attached to the frame of the wooden frames, and the entire construction is disassembled for easy transport. The advantages of such origami structures are the use of relatively small elements, which facilitates transport and reduces the cost of production, and their multiplication can be obtained by extremely dynamic compositions. In this way, a running, playful structure is obtained, suitable for sitting at different heights and in different positions. Due to the change in the level (Figure 1-b), from 20 to $90 \mathrm{~cm} \mathrm{high,}$ this installation, in addition to the seating function, can also be used as a lectern. In this sense, the sculptural installation is an extremely flexible space, which functionally satisfies the needs of different groups of users. In addition, it also possesses visual qualities, enriching the urban - public space (open or closed). As for the name "forum" it refers to getting together, socializing, communion, sharing and debating ideas.

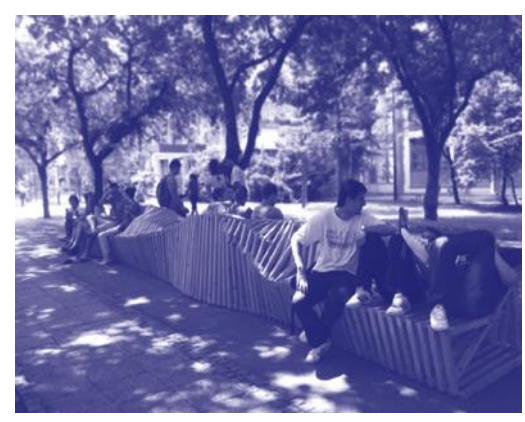

a)

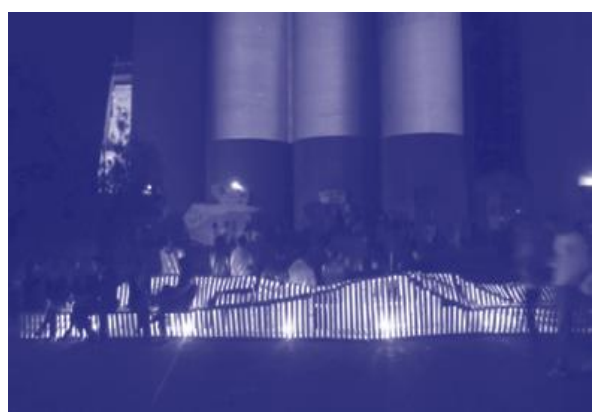

b)

Fig. 2 (a) Bench $1000 \mathrm{~cm}$, (b) Bench $1000 \mathrm{~cm}$, night view (source: www.gradjanske.org/ wp.../059-Otvoreno-o-javnim-prostorima.pdf, accessed: 12.03.2018)

The bench $1000 \mathrm{~cm}$ (Figure 2-a) was also created in 2011 in cooperation with the Faculty of Technical Sciences in Novi Sad and the municipality of Dimitrovgrad. The form of the object is achieved by computer parametric modeling, and then translated into a physical form. The structure is made of wooden slats, where the full and hollow parts appear alternately, which, in combination with interior lighting (Figure 2-b), gives interesting light effects. The length of the structure is $10 \mathrm{~m}$, but it gives itself to unlimited extension, or shortening, in accordance with the needs and size of the space.

The installation served as an exhibition space and showpiece; project posters were displayed on it, and at the same time it served as a seating furniture. Therefore, the project is multifunctional, its use value is large, and that is making it extremely suitable for different spaces.

To make a long story short, these two projects are specific micro-urban ephemeral interventions of certainly great importance in the revival of the public space, both open and closed. Their advantages are low cost and relatively fast construction, but also their attractiveness; both projects represent space refreshment and a "magnet" for users.

\subsection{Pavilions - structures of unique shapes}

A good example of the use of ephemeral structures in promoting art and establishing a social contact is the Serpentine Gallery, the famous London gallery located in Kensington 
Gardens in Hyde Park. From the year 1970 until today, it promotes contemporary art and architecture through a series of events in the fields of art, culture and education (source: https://www.theguardian.com/artanddesign/2010/may/23/serpentine-pavilions-ten-yearson, accessed: 12.03.2018.)

Zaha Hadid was invited in 2000 to design an ephemeral structure - the pavilion. The pavilion had a great success and the visitors were very interested in the structure (Figure 3-a), so it stayed next to the gallery object for three months. Since then, each year the Serpentine Gallery has been hiring leading architects of the world to design ephemeral structures.

The development of the formalist approach is monitored through insights into the project from 2001, when Daniel Libeskind was hired for his creation. The Serpentine pavilion in 2001 is based on the idea of a flexible origami materialized in steel and reflecting aluminum panels (Fig. 3-b), which in the interior left the impression of more maze space than the space for people to stay and the presentation of works of art. His title "The Eightfold Turn" was a sculpture by itself, which establishes communication exclusively with the context of the park, reflecting the greenery over its polished envelope.

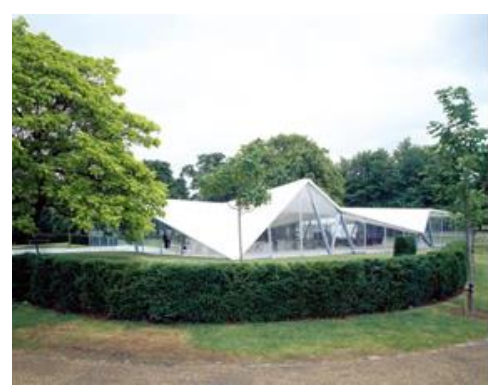

a)

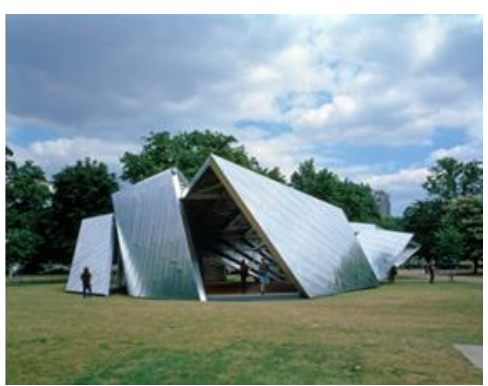

b)

Fig. 3 (a) Personification of tents and origami, pavilions from 2000, (b) from 2001, successive (source: https://www.theguardian.com/artanddesign/2010/may/23/serpentinepavilions-ten-years-on, accessed: 12.03 .2018$.

The first step towards the adoption of the social context and relations with the users of the pavilion was made by Tojo Ito in 2002. Designing a complex cubic, semi-transparent, closed-open spatial structure (Figure 4-a), the architect designed an object that invites the Hyde Park visitor to enter inside and feel a unique space with constant change of light and shadow, a semi-permeable membrane surrounding an event unfolding in the interior. The intrigue of the structure is based on the complex algorithmic execution of the cube at rotation. Forms derived from this, in the form of translucent and transparent modules of triangles and trapezes, complement the idea of continuous change within the space. For the first time then, the spatial architectural envelope enabled socialization in its interior, while at the same time it remained closed and open to the world of the park around it.

The structure between the idea and the reality in 2006 was realized by pavilion of Rem Kolhas, by projecting a huge balloon above the observed amphitheater (Figure 4-b), and realizing the spectacular picture of the grounded Moon in the park. The sensational picture of the illuminating ball above the Serpentine gallery in the interior still did not 
reach its goal. Namely, just above the required amphitheater air space, this technical egg was closed from below for technical and technological reasons.

Two years after the levitating balloon construction, the pavilion project in Hyde Park gets a diametrically opposite shape. Designed by Frank Gery as a semi-public and semiproprietary space with axially set street in the park, it realized the idea of connecting the park and the gallery with a transitional structure. A somewhat eccentric form, according to which Geri is known, due to the existence of four steel columns lined with wood (Figure 4c), which are similar with the wooden capitals of Leonardo da Vinci, the architect justifies with the need for finding inspiration in historical facts. The construction, although actually opened on both sides of the axis, still gives the impression of a closed space in which contact is possible only in its interior. The amphitheatric staircase on both sides, which is in function of the place for rest and observation of the promenade, was the place of gathering of visitors, clearly defining the central space of the street as a binary space.

Although seemingly completely different, the analyzed pavilions share the common quality of establishing a spontaneous social contact during their existing in the Hyde Park. In all three cases, the contact is enabled by mastering the pavilion envelope, which, as a semi-permeable membrane, misses events from its inside into the outer park world. It is interesting that all three examples show a more dramatic appearance at night - with special lighting systems, completely different in all three cases.

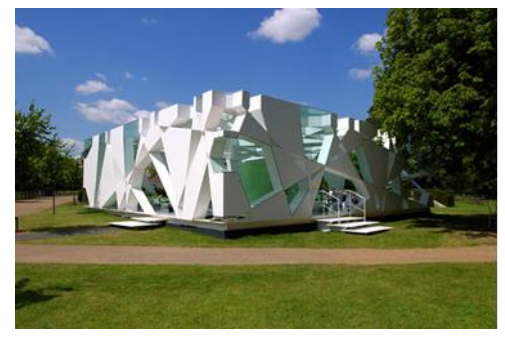

a)

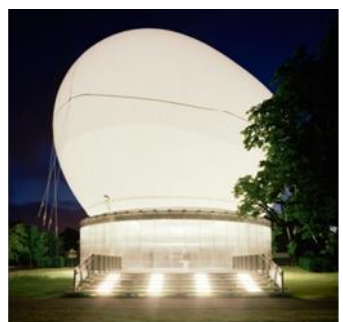

b)

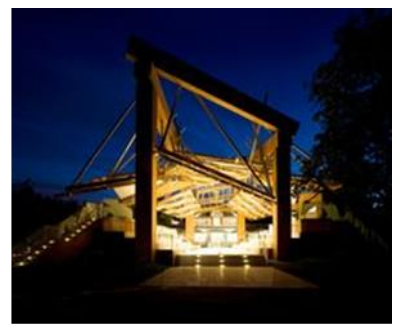

c)

Fig. 4 (a) Challenge to establish contacts, pavilions from 2002, (b) 2006, and (c) 2008 Successive (source: https://www.theguardian.com/artanddesign/2010/may/23/serpentinepavilions-ten-years-on, accessed: 12.03.2018.)

\subsection{Ephemeral formations of ship containers}

Together with the expansion of industrial exchanges after the Second World War ship containers are used - modular units, of standardized dimensions - as a certain element of globalization. The design of a prototype made of steel and tin panels became a global determinant for conquering the world by containers (Figure 5), in terms of the development of the use of ship containers, especially in architecture and art (source: Heins, 2013, accessed: 12.03.2018.). It could be said that the recycling of used containers through their reuse in architecture, the very foundation of ephemeral architecture is a category. 

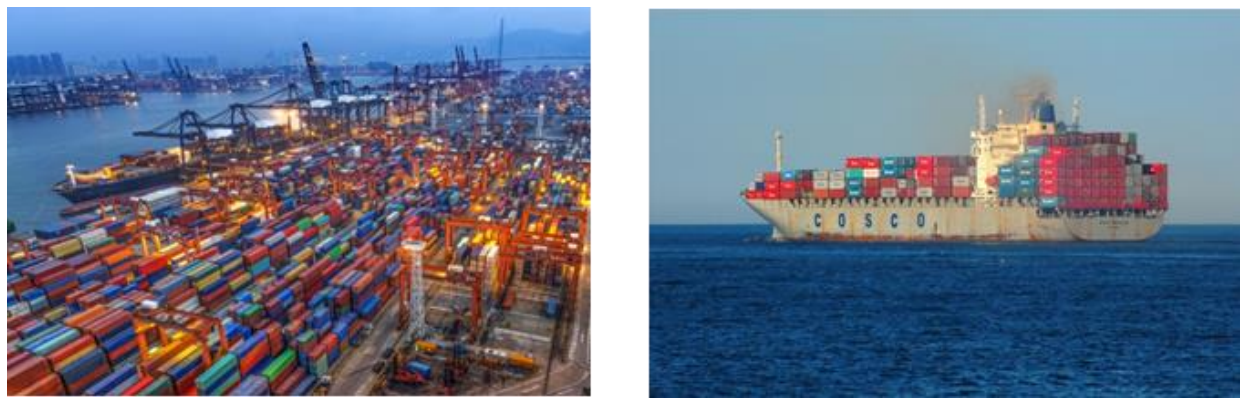

Fig. 5 Ephemeral formations of ship containers - visually and functionally challenging (source: Heins, 2013, accessed: 12.03.2018)

Observed at the level of art installation, the container space finds creative use as the initial space of the event itself. Between 2013 and 2014, the creative team of Shared Studios and Ema Critchley come conceptually to a very similar idea about the use of ship container spaces as the space for the presentation of their artistic ideas. The concept was simple - two people on different geographical coordinates, enter into containers and agree to get to know each other and interact. This is enabled by placing the projection screen of the cross-section dimensions of the container in its interior, and by designing live transmission from another container (Figure 6), while the person is inside. Shared Studios encourages artists to create in an ephemeral isolation, creating a kind of shared space, enabled by technology. Underwater artist, photographer and cameraman, Ema Critchley, brings additional artistic value to the described concept.
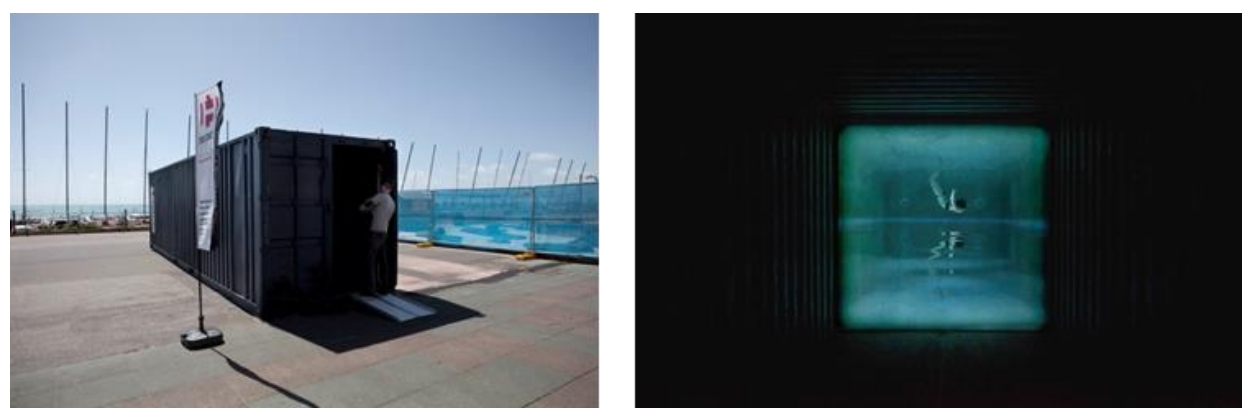

Fig. 6 Ship Container - physical spatial frame and interior space realized by art installation "Aria" (source: http://emmacritchley.com/installations/aria/, accessed: 12.03.2018.)

The idea was to stretch a semi-transparent projection screen across the entire crosssection of the container, at a certain distance from the front door, and to project a material from the pool to the screen. The semi-transparency of the screen made it possible to identify the observers with the event in the pool because the projected material received an additional layer of spatial determination by overlapping with the perspective of the containers, materials and dimensions. In this installation there is a blur of clear boundaries 
between the interior and exterior, between the dimensions of the box and the dimensions of the pool, between air and water. The observer seems to think that the body of the diver sails far in the perspective which is, it can be said - at the reach of your hand, the illusion is complete, the diver, the soprano and the observer share a unique space - the interspace that quotes on the mental reconfiguration (source: http://emmacritchley.com/installations/aria/, accessed: 12.03 .2018$.

\section{CONCLUSION}

By pointing out the importance of the domain of ephemeral architecture, its ideas, its forms and its scope in the overall consideration of architectural phenomena today, this research formulates several conclusions. Compared to permanent architectural structures, those that are ephemeral satisfy some of the functions, which permanent structures do not satisfy for various reasons. The ability to reuse and rely on non-invasive construction methods makes ephemeral structures suitable for quick installation in different locations, while having a low environmental impact. Portable architecture is particularly suitable for incorporating new technological achievements, and its excellence is based on the principles of design efficiency, ease and flexibility. A very important function of this structure is the temporal durability of the consequences that its occurrence may have, even when its temporality removes evidence of its physical existence.

A detailed analysis of the specific type of ephemeral structures is the pavilion, which indicates the potential of this form. Pavilions are a good example of promoting contemporary art, architecture and technology through a series of events in the fields of culture and education, with the establishment of spontaneous social contact. Development of the phenomenon of the ship containers use in architecture and art conditioned its creative application at the level of artistic installation or the space of presentation of artistic ideas.

The ephemeral spatial framework that arises in temporary change of object purpose that have been denied their original function, is of particular importance for clarifying the influence of the domain of ephemeral architecture. Spatial transformations that determine the ephemeral frame contain unique qualitative factors that determine the quality of art narratives in it.

Considering that the task of art and architecture is to reconstruct the experience of an undifferentiated inner world, in which we are not only observers, but to whom we belong, we conclude that ephemeral architecture has the function of establishing a temporary spatial framework of this type of artistic events, and adequately fulfills it.

Acknowledgement: The paper was done within the scientific project No TR36045 in cooperation with the Ministry of Education, Science and Technological Development, Republic of Serbia.

\section{REFERENCES}

Chappel, B., (2006), Ephemeral architecture - Towards a Definition, https://www.scribd.com/document/ 193497347/Ephemeral-Architecture, e-publication.

Coar, L., (2011), "The Lasting Meaning in Ephemeral Architecture", Design Principles and Practices, vol.5(6), pp.667-678.

Gidion, S., (2002), Prostor, vreme i arhitektura, Građevinska knjiga, Beograd. 
Heins, M., (2013), The Shipping Container and the Globalization of American Infrastructure, University of Michigan.

Kronenburg, R, (1998), Transportable Environments: Theory, Context, Design and Technology, Routledge, London and NY.

Mellado Paz, D., (2012), Arquitetura efêmera ou transitória, http://www.vitruvius.com.

Pantović, K, Parežanin, V., Kavran, J., (2013), "Teritorija privremene arhitekture", Međunarodni naučno - stručni simpozijum Instalacije i arhitektura, Beograd, pp.118-126.

Radović, R., (2003), Forma grada - osnove, teorija i praksa, Orion ART, Beograd.

Uzunović, M., (2009), Studija urbanih elemenata otvorenih prostora u cilju adekvatne socijalne integracije, Nauka+praksa, Građevinsko-arhitektonski fakultet, Niš, pp.234-237

Zeković M., (2015), Efemerna arhitektura u funkciji formiranja graničnog prostora umetnosti, Doktorska disertacija, Novi Sad.

Zite, K. (2004), Umetničko oblikovanje gradova, Građevinska knjiga, Beograd.

Walker, J., (2004), "Ephemeral architectures: The body and landscape in augmented reality", Digital creativity, vol.15, pp.93-97.

www.gradjanske.org/wp.../059-Otvoreno-o-javnim-prostorima.pdf

https://www.theguardian.com/artanddesign/2010/may/23/serpentine-pavilions-ten-years-on

http://emmacritchley.com/installations/aria/

\section{EFEMERNA ARHITEKTURA - PREDLOG INTERVENCIJA U JAVNOM PROSTORU}

Osnova fizičke strukture grada svakako su arhitektonski objekti, ali kao posebne morfološke i tipološke celine, to su slobodni prostori izuzetnih vrednosti i karaktera. Objekti koji formiraju prostore gradova često se menjaju, grade i razgrađuju, ali kao trajni motiv gradskog prostora ostaje - prazan, neizgrađen deo, kao konstantni znak istorije. Na hijerarhijskoj lestvici urbanog ambijenta, važni elementi su efemerne strukture, stalne ili privremene. Mogućnost oživljavanja praznog prostora je instalacija umetničkih ili efemernih utilitarnih struktura. Ovaj rad predstavlja ulogu takvih mikrourbanističkih intervencija koje obogaćuju javni prostor i doprinose njegovoj revitalizaciji. Efemerna arhitektura je posebno pogodna kao prostor za prezentaciju umetničkih ideja i za uvođenje novih tehnoloških dostignuća. Cilj rada je da se sagleda važnost efemernih struktura analizirajući $i$ proučavajući studije slučaja. Naglasak je stavljen na primere završenih projekata paviljona jedinstvenih oblika i na korišćenje brodskih kontejnera kao prostora za prezentaciju umetničkih ideja. Glavni doprinos ovog rada trebalo bi da bude predlog korišćenja efemernih struktura u oživljavanju urbanog prostora, promovisanje umetnosti i uspostavljanje socijalnog kontakta.

Ključne reči: Efemerna arhitektura, Mikro-urbanistička intervencija, Instalacije, Paviljoni, Umetnost. 